\title{
THE CORRELATION BETWEEN GENERIC STRUCTURE MASTERY AND THE STUDENTS' ABILITY IN WRITING NARRATIVE TEXT AT THE GRADE VIII IN SMP NEGERI 3 PADANGSIDIMPUAN
}

\author{
NURDIANA, EKA SUSTRI HARIDA, \& MISRAYANA HARAHAP \\ Universitas Muhammadiyah Tapanuli Selatan \\ email: esha_stainpasid@yahoo.com
}

\begin{abstract}
Abstrak
Penelitian ini adalah penelitian korelasi yang bertujuan untuk mengetahui signifikansi hubungan antara pengetahuan siswa kelas VIII SMP Negeri 5 Padangsidimpuan terhadap generic structure (struktur teks) dan kemampuan mereka dalam menulis teks naratif. Sampel yang dihunnuk untuk emwakili populasinya adalah sejumlah 38 siswa yang dipeorleh melalui teknik pengambilan sampel kluster. data penelitian dipeorleh dengan tes pilihan berganda ungtuk variable generic structure dan tes essai menulis sebuah teks naratif untuk variable kemampuan siswa dalam menulis. Data dianalisis melalui uji hipotesis " $\tau$ ". Dari hasil analisis diketahui bahwa kemampuan struktur teks dan menulis siswa kelas VIII SMP Negeri 5 Padangsidimpuan pada kondisi baik. Untuk hubungan antara kedua variable dapat dinyatakan signikan karena nilai $r$ hitung lebih besar daripada r-table. Oleh karenanya hipotesis diterima, yakni terdapat hubungan yang signifikan antara penguasaan siswa pada struktur teks dan kemampuan menulis teks naratif.
\end{abstract}

Kata Kunci: Generic Structure, Writing, Mastery and Ability.

\begin{abstract}
The research conducted at SMP Negeri 3 Padangsidimpuan, the aims of this research is to find out research the correlation between generic structure Mastery and The Students' Ability in Writing Narrative Text of the grade VIII SMP Negeri 3 Padangsidimpuan. The population of this research consisted 328 students and sample of this were 38 students that were taken by cluster sampling. In collecting the data needed, the writer used instrument multiple choice and essay test. In order to analyze the data to the test the hypothesis is accepted or rejected, it was tested by using the formula " $\tau$ ". After analyzing and the data of the research, it found that the grade VIII of students SMP Negeri 3 Padangsidimpuan in 2012/2013 academic year about generic structure mastery is Very Good namely because after calculated their
\end{abstract}


score it found that the total score of them was 3093. Thus, the total mean score of the students was 81,39 and the grade VIII of students SMP Negeri 3 Padangsidimpuan writing narrative text is Good namely, because after calculated their score it found that the total score of them 78,42 . Dealing on the result of the tabulation, it can be found that the value of rxy was 0,863. It means that there was significant The correlation between generic structure mastery and the students' ability in writing narrative text at the grade VIII in SMP Negeri 3 Padangsidimpuan.

Keywords: Generic Structure, Writing, Mastery and Ability.

\section{INTRODUCTION}

Language is a connection of human right in our society, English is one language. Which function as the mean of communication. It controls fact human existence and social process. It is also something important in our life. By using english language a person can transfer his or her tought, feeling ideas and desire to another or to whom he tells in the word if he students one not being able master it the will get difficulties in that study. It can be form the instruction of our goverment especially for student of junior high school.

English is the language used must people in every country it is a means communication to interact each other. In education system most of scientific resources, such as books and articles are variable in english.

Realizing how important English is the goverment of Indonesia has decided that English should be taught at schoool as the first foreign language. From primary school up to collage level. The effort of the goverment of Indonesia will enlarge Indonesia students knowledge in English.

There are four basic aspect in language, it's speaking, reading, writing and listening. Speaking is the process of expressing idea, feeling experience by using sound, tone, and speed. Reading is process to know and to understand about the information from the book to the reader. Writing is the process of expressing idea or information from the writer. Listening is the process for the listen about information from one people to other people. In this research writer will more explain about writing. Especially writing narrative text.

In writing narrative there are some aspects that important to know, one of them generic structure. As to know generic structure is about story in a text or step to step about topic information in texts, generic structure identical with plot. In make a text narrative generic stucture it's very important, because in narative 
text very influence to the text. So, student must understand about generic structure before make a narrative text.

As the writer's experiences when PPL, the writer found that many students are not able to write well, even in narrative text caused they not understand how the generic structure. They fell difficulties write a text well cause of they taught by their teacher in traditional way and their teacher never asked them to write a text. So, they less of excercises in writing.

Based on the problem in this research, writer can to conclusion students must understand about generic structure for to can make narrative text. So, student must more can to studying about generic structure and also teacher must giving explaining about generic structure. So, student not confusing about generic structure and what the function generic structure in narrative text.

In this research writer will explain about generic structure. And, how the write narrative text and for to students will to know about generic structure and can writing narrative. Because about that, writer want to know about correlation between generic structure mastery and the students' ability in writing narrative text at the grade VIII in SMP Negeri 3 Padangsidimpuan 2012/2013 Academic Year.

The purpose to the research follows:

1. To find out the extend of grade VIII students SMP Negeri 3 Padangsidimpuan 2012/2013 academic year in ability the generic structure mastery.

2. To find out the VIII students' in writing narrative text at SMP Negeri 3 Padangsidimpuan.

3. To find out the correlation between generic structure mastery and students' ability in writing narrative text at grade VIII students SMP Negeri 3 Padangsidimpuan 2012/2013 Academic Year.

\section{THE THEORETICAL DESCRIPTION}

\section{The Concepts of Writing}

Writing was one of the four language skills besides listening, speaking and reading. It is a process of stating the ideas written; it is "the act or process of one who writes" 1 . Writing is also a combination of process and product of

1 Merriam Webster, “Merriam-Webster Dictionary,” merriam-webster.com, 2017, https://www.merriam-webster.com/dictionary/writing. 
314 | TAZKIR: Jurnal Penelitian Ilmu-ilmu Sosial dan Keislaman

Vol. 03 No. 2 Desember 2017

thinking, in which gathering ideas and working with the ideas then produced it to be read ${ }^{2}$. Writing conveys the writer's thought in the written form as Harmer ${ }^{3}$ that writing process is the stage written goes trough in order to produce something in its final written form or written. Accordingly, writing is also physical and mental act ${ }^{4}$ in which the writers relate their ideas and physic to give the ideas. In other ways, it can be stated that writing is a process and a product in which the people state to other people in written forms.

When someone writes, he tells the ideas to be informed to the readers. By writing, people can transfer their knowledge. Writing can explore the ideas, and the writer can give many things by this activities. Writing is the way of someone to state the ideas in the form of writing.

As it known that there were many types of writing they were exposition, description, narration and argumentation. Narration or narrative provides details of telling a story further. According to Langgan ${ }^{5}$ narration was story telling which was relating a single srory or several related ones. Bretton and Hornby" defined about narrative stated that "narrative was spoken or written account of event a story also". In addition Miller ${ }^{7}$ that "narration was a type of composition gives an account of events or experience in time". The story may be true as in the writing of history, autobiography or news reports. The story may be fictional as in a short story, novelette. An effective narration has a plot it was arranged according to meaningful and dramatics sequence of action which may or may not follow the order in which event actual happened.

According to Dietch ${ }^{8}$ the purpose of narrative may be to reflect, entertain, inform explain or persuade. So, narrative writing is to give the

${ }^{2}$ Caroline Linse and David Nunan, Practical English Language Teaching: Young Learners (New: McGraw-Hill Companies, Inc., 2005).

3Jeremy Harmer, "How to Teach English: An Introduction to the Practice of English Language Teaching," Longman Ninth Impression, 1998.

${ }^{4}$ Rayendriani Fahmei Lubis, "The Comparative Study of Grammar Translation Method (GTM), Task Based Language Teaching (TLBT), and Contextual Learning and Teaching (CLT) in Writing Sentences at SMP Swasta Nurul Ilmi," TAZKIR: Jurnal Penelitian Ilmu-Ilmu Sosial Dan Keislaman 2, no. 1 (August 1, 2016): 159, https://doi.org/10.24952/tazkir.v2i1.408.

${ }^{5}$ Diane Larsen-Freeman and Michael H. Long, An Introduction to Second Langguage Acquisition Research (New York: Routledge Taylor \& Francis Group, 2014).

${ }^{6}$ Bretton and Hortory. 1995. Writing Narrative Scientific Research Articles Srategy and The Steps. Australia : Willey Blackwell.

${ }^{7}$ Miller. 1997. Writing strategies Creative, Newyork: Learning Express.

${ }^{8}$ Dietch. 2003. Writing Teaching Guide, Sidney : Langosch. 
entertainment to the readers and to make them interest to read the written. In narrative text, there are the structure in general that the writers must follows, as orientation, incidents or climax or conflicts, sequence of events, and resolution, and coda.

\section{METHODOLOGY OF RESEARCH}

The writer conduct of this research by using correlative type, because the writer wants to find out how the correlation the variables of the research clearly. The population of this research is 328 students VIII grade student of SMP Negeri 3 Padangsidimpuan, and the sample was 38 students as sample. In this research the writer applied written test for the instrument of the collecting data. The intrument is should be appropriate with the variable of the research and they are $X$ variable which is for generic struture mastery and $Y$ variable. For the generic structure mastery, it is multiple choice test, and for the writing narrative text, it is to write a narrative text with the generic structure. The data procedure are conducted as follow:

a. The question and answer sheets are first distributed

b. The students read the instructions and then the writer gave the time limitation for the test.

c. The writer gave the time or chance for the students to ask something left or not clear in doing test.

d. The writer asked students to do test and avoid cheating or peeping. The writer looks after the students during the left, finally collect the test.

Before analyzing the result of collecting data the writer needs to classify the criteria of score. The score is counted by mean-score and correlation.

\section{FINDINGS}

\section{Description of the Data}

As stated above that the instrument for collecting data of this research conducted by using a test, it is written test, where as the test used to examine the studnts of in writing narrative. It means that the writer asked the students to write text. However, the total score of thr test is 100.

After examining the grade VIII students of SMP Negeri 3 Padangsidimpuan in writing text, the writer scored their answers. After collecting the data .So, the students score can be seen in the following table : 
316 | TAZKIR: Jurnal Penelitian Ilmu-ilmu Sosial dan Keislaman Vol. 03 No. 2 Desember 2017

Table 1: The students' score of Generic Structure :

\begin{tabular}{|c|c|c|}
\hline NO & Name of Students (n) & Score of Students \\
\hline$(1)$ & $(2)$ & (3) \\
\hline 1 & A N & 90 \\
\hline 2 & A N S & 80 \\
\hline 3 & A P & 86 \\
\hline 4 & $\mathrm{~A} Z$ & 83 \\
\hline 5 & ANSH & 84 \\
\hline 6 & A S R & 83 \\
\hline 7 & B M H M & 92 \\
\hline 8 & D P L & 83 \\
\hline 9 & DWY & 90 \\
\hline 10 & D P S & 65 \\
\hline 11 & D SY P & 82 \\
\hline 12 & D F S & 80 \\
\hline 13 & E V C N & 87 \\
\hline 14 & E SW Y & 80 \\
\hline 15 & HS & 95 \\
\hline 16 & JS L T & 75 \\
\hline 17 & LAS & 95 \\
\hline 18 & M N A & 65 \\
\hline 19 & M A & 87 \\
\hline 20 & MYS & 80 \\
\hline 21 & $\mathrm{M} \mathrm{ZF}$ & 95 \\
\hline 22 & $\mathrm{~N} \mathrm{~J}$ & 75 \\
\hline 23 & R S D & 84 \\
\hline 24 & $\mathrm{RA}$ & 82 \\
\hline$(1)$ & $(2)$ & (3) \\
\hline 25 & R A A D & 75 \\
\hline 26 & R H D & 84 \\
\hline 27 & RK & 70 \\
\hline 28 & R M D & 86 \\
\hline 29 & RZ A & 65 \\
\hline 30 & RZ F & 65 \\
\hline
\end{tabular}




\begin{tabular}{|c|c|c|}
\hline NO & Name of Students (n) & Score of Students \\
\hline 31 & STHD & 82 \\
\hline 32 & S NF & 75 \\
\hline 33 & SASY & 85 \\
\hline 34 & S RY P & 82 \\
\hline 35 & VT & 80 \\
\hline 36 & WND & 92 \\
\hline 37 & WD P & 84 \\
\hline 38 & Z A R I & 75 \\
\hline & Total & $\mathbf{3 0 9 3}$ \\
\hline
\end{tabular}

From the table above the writer got total are 3093. To make computation of the generic structure mastery in saw in appendics V. Where is it the formula of the mean is

$$
\begin{aligned}
& M=\frac{\sum x}{3098} \\
& =\frac{38}{38} \\
& =81.39
\end{aligned}
$$

From the score it was gained that the mean of score was 81,39 . So, it can be conclude that the generic structure mastery of the VIII grade student of SMP N 3 Padangsidimpuan was Very Good, because, it was mean that the students had gotten score higher more than from KKM in SMP N 3.where KKM in SMP N 3 is 70. In this researh writer maked the first variable about generic structure.

Based on the table frecuency distribution above, the writer got that the students who got score from $65-69$, there are 4 students or $10,53 \%$. The students who got score from $70-75$, there are 6 students or $15,78 \%$. The students who got score from $76-80$, there are 6 students or $15,78 \%$. The students who got score from $81-85$, there are 12 students or $31,57 \%$. The students who got score from $86-90$, there are 5 students or $13,15 \%$ and then the students score $91-95$, there are 5 students or $13,15 \%$.

\section{Descriptive Data of Students' ability in Writing Narrative Text}

The score rank of the respondents in variable of writing is not far from variable of generic structure mastery and narrative text. The results score of 
318 | TAZKIR: Jurnal Penelitian Ilmu-ilmu Sosial dan Keislaman Vol. 03 No. 2 Desember 2017

writing ability in the second test are distributed from 70 until 95. The calculated data can be seen below :

Table 2 The data of variable writing narrative text

\begin{tabular}{|c|c|c|}
\hline No & Name of Students (n) & Score of Students \\
\hline 1 & A N & 80 \\
\hline 2 & A N S & 75 \\
\hline 3 & A P & 75 \\
\hline 4 & AMJ & 70 \\
\hline 5 & $\mathrm{~A} Z$ & 80 \\
\hline 6 & ANSH & 80 \\
\hline 7 & A S R & 82 \\
\hline 8 & B M H M & 83 \\
\hline 9 & D P L & 82 \\
\hline 10 & DWY & 95 \\
\hline 11 & DPS & 85 \\
\hline 12 & D SY P & 60 \\
\hline 13 & D F S & 65 \\
\hline 14 & E V C N & 80 \\
\hline 15 & E SW Y & 95 \\
\hline 16 & $\mathrm{HS}$ & 82 \\
\hline 17 & J S L T & 75 \\
\hline 18 & LAS & 88 \\
\hline 19 & M A & 60 \\
\hline 20 & MYS & 82 \\
\hline 21 & $\mathrm{M} \mathrm{ZF}$ & 95 \\
\hline 22 & $\mathrm{~N} \mathrm{~J}$ & 70 \\
\hline 23 & R S D & 86 \\
\hline 24 & $\mathrm{R} \mathrm{A}$ & 70 \\
\hline 25 & $\mathrm{RY}$ & 85 \\
\hline 26 & R A A D & 83 \\
\hline 27 & R H D & 82 \\
\hline 28 & RK & 75 \\
\hline 29 & R M D & 85 \\
\hline 30 & RZ A & 90 \\
\hline
\end{tabular}




\begin{tabular}{|c|c|c|}
\hline No & Name of Students (n) & Score of Students \\
\hline 31 & RZ F & 70 \\
\hline 32 & STHD & 75 \\
\hline 33 & S NF & 75 \\
\hline 34 & SASY & 60 \\
\hline 35 & S RY P & 75 \\
\hline 36 & VT & 70 \\
\hline 37 & WND & 80 \\
\hline 38 & WD P & 80 \\
\hline & Total & $\mathbf{2 9 8 0}$ \\
\hline
\end{tabular}

From the table above the writer got total score 2980. To make computation of the writing narrative text in saw in appendics V. Where is it the formula of the mean is :

$$
\begin{aligned}
M= & \frac{\sum x}{n} \\
& =\frac{2980}{38} \\
& =78.42
\end{aligned}
$$

The mean of the score was 78,42 and the median was 75,5 . Based on the formula, the mean score that got by the students can concluded that writing narrative text was Good. The writer saying good because in the writing narrative text the students are able to write good writing of generic structure in their writing, they had written the descriptive text in exact generic structure.

\section{The Testing of Hypotesis}

In order looked for the reality od hypothesis that proposed beforein this research weather accepted or refuse. So, that do testing by hypothesis by used correlation the value of " $\tau$ " was calculated by applying the statistic formula from M. Iqbal Hasan. Before going to the, firstly the writer wants to the describe the calculation of the data on the table as performed in the following : 
320 | TAZKIR: Jurnal Penelitian Ilmu-ilmu Sosial dan Keislaman

Vol. 03 No. 2 Desember 2017

Table 3: The distribution generic structure mastery and students' ability and writing narrative text.

\begin{tabular}{|c|c|c|c|}
\hline NO & NAME OF STUDENTS (N) & $x$ & $\mathbf{Y}$ \\
\hline 1 & A N & 90 & 80 \\
\hline 2 & A N S & 80 & 75 \\
\hline 3 & A P & 86 & 75 \\
\hline 4 & $\mathrm{~A} Z$ & 83 & 70 \\
\hline 5 & ANSH & 84 & 80 \\
\hline 6 & A S R & 83 & 80 \\
\hline 7 & B M H M & 92 & 82 \\
\hline 8 & D P L & 83 & 83 \\
\hline 9 & DWY & 90 & 82 \\
\hline 10 & D P S & 65 & 95 \\
\hline 11 & D SY P & 82 & 85 \\
\hline 12 & D F S & 80 & 60 \\
\hline$(1)$ & (2) & (3) & $(4)$ \\
\hline 13 & E V C N & 87 & 65 \\
\hline 14 & E S W Y & 80 & 80 \\
\hline 15 & $\mathrm{HS}$ & 95 & 95 \\
\hline 16 & J S L T & 75 & 82 \\
\hline 17 & L A S & 95 & 75 \\
\hline 18 & M N A & 65 & 88 \\
\hline 19 & M A & 87 & 60 \\
\hline 20 & M Y S & 80 & 82 \\
\hline 21 & $\mathrm{M} \mathrm{ZF}$ & 95 & 95 \\
\hline 22 & $\mathrm{~N} \mathrm{~J}$ & 70 & 70 \\
\hline 23 & R S D & 84 & 86 \\
\hline 24 & $\mathrm{RA}$ & 82 & 70 \\
\hline 25 & RA A D & 75 & 85 \\
\hline 26 & R HD & 84 & 83 \\
\hline 27 & RK & 70 & 82 \\
\hline 28 & RM D & 86 & 75 \\
\hline 29 & RZ A & 65 & 85 \\
\hline
\end{tabular}




\begin{tabular}{|c|c|c|c|}
\hline NO & NAME OF STUDENTS (N) & $\mathbf{X}$ & $\mathbf{Y}$ \\
\hline 30 & RZ F & 65 & 90 \\
\hline 31 & STHD & 82 & 70 \\
\hline 32 & S NF & 75 & 75 \\
\hline 33 & SASY & 85 & 75 \\
\hline 34 & S RY P & 82 & 60 \\
\hline 35 & VT & 80 & 75 \\
\hline 36 & WND & 92 & 70 \\
\hline 37 & WD P & 84 & 80 \\
\hline 38 & Z A R I & 75 & 80 \\
\hline & Total & $\mathbf{3 0 9 3}$ & $\mathbf{2 9 8 0}$ \\
\hline
\end{tabular}

Then, the data were processed and analyzed through " $\tau$ " . Becouse, the researcher wants to describe the correlation of both variable. The value of " $\tau$ " was calculated by applying the statistic formula from M. Iqbal Hasan.

$$
\begin{aligned}
\tau & =\frac{S}{\sqrt{\frac{1}{2}} N(N-1)-T x \sqrt{\frac{1}{2} N(N-1)-U y}} \\
\tau & =\frac{527}{\sqrt{1 / 238(38-1)-78 \sqrt{1 / 238(38-1)-105}}} \\
& =\frac{527}{\sqrt{(19)(37)-78 \sqrt{(19)(37)-105}}} \\
& =\frac{527}{\sqrt{625} \sqrt{598}} \\
& =\frac{527}{\sqrt{25 \sqrt{24.4}}} \\
& =\frac{527}{610} \\
& =0.863
\end{aligned}
$$

Then result calculation above shows that the correlation between generic structure mastery and the students' ability in writing narrative text was 0.860 .It means, the relation between both variables was very strong.They should be judged Sugiono's nation (2010:184) about the categories interpretation of correlation bellow: 
322 | TAZKIR: Jurnal Penelitian Ilmu-ilmu Sosial dan Keislaman

Vol. 03 No. 2 Desember 2017

\begin{tabular}{|c|c|}
\hline Interval Coefficient & Correlation Degree \\
\hline $0.00-0.199$ & Weakness \\
\hline $0.20-0.399$ & Weak \\
\hline $0.40-0.599$ & Middle \\
\hline $0.60-0.799$ & Strong \\
\hline $0.80-1.000$ & Very strong \\
\hline
\end{tabular}

Based the calculation and explanation above, the value of " $\tau$ " was

0.860 . The hypothesis was accepted. It can be concluded, there was significant correlation between generic structure mastery and students' ability in writing narrative text. The hypothesis in this research that stated,There was a significant correlation between generic structure mastery and the students' ability in writing narrative text at the grade VIII in SMP Negeri 3 Padangsidimpuan in 2012/2013 Academic Year.

Based on the above calculation, it can be known that $r x y=0,863$ it is concluded to the categories of correlation coefficients in previous chapter is categorized " high correlation".

To got the answer of the hypothesis that conducted before, namely " there was significant correlation between generic structure mastery and the students' ability in writing narrative text at the grade VIII in SMP Negeri 3 Padangsidimpuan in 2012/2013 academic year". So, the writer do testing hypothesis. Where correlation is the students ability in writing narrative text of generic structure mastery that if students understood about generic structure and can diffrent between kinds of generic structure, student can diffrent about Orientation, Re-orientation/Conflict, Resolution and Coda, automatically students understand can of writing narrative text and generic structure and can writing English with good.

Further, the writer determined the hypothesis whether the hypothesis is alternative hypothesis. Means that ability in generic structure is important skill that crucial supported to the students ability in writing narrative text. Another hypothesis is null hypothesis means that there is no correlation of variable $\mathrm{X}$ forward variable $\mathrm{Y}$.

Based the calculation and explanation above, the value of " $\mathrm{t}$ " was 0,863 . The hypothesis was accepted. It can be concluded, there was significant correlation between generic structure mastery and the students' ability in writing narrative text at the grade VIII in SMP Negeri 3 Padangsidimpuan. 
From the findings, it is known that there is the correlation between the generic structure mastery and the students' ability in writing narrative texts. It has been agreed to understanding something is needed for comprehending the others ${ }^{9}$. Moreover, not only structures, teaching writing also needs some methods, that many methods can give good effect to teach writing ${ }^{10}$. In addition, it has been found that more vocabulary has more good the students in writing ${ }^{11}$. Based on this, it really stated that writing needs more support, not only generic structure of the texts, but also vocabulary, teaching methods and others.

\section{CONCLUSION AND SUGGESTION}

In this chapter the writer the conclusion and suggestion based on the result of the research. After analyzing the data collected from the respondents, then writer concludes and suggest as following.

\section{The Conclusion}

The conclusions of this research are stated as follows :

1. The ability of the VIII grade students of SMP Negeri 3 Padangsidimpuan in Generic structure in categories "Very Good" which the mean score was 81.39 .

2. The ability of students SMP Negeri 3 Padangsidimpuan in writing narrative text in categories "Good". It can be known that the students can understand and able to write narrative text. The means score of the narrative text was 78.42 .

3. So, the hypotesis there is a significant correlation between generic structure mastery and the students' ability in writing narrative text at the grade VIII in SMP Negeri 3 Padangsidimpuan in 2012/2013 academic year. Based on the result correlation between variable $\mathrm{x}$ and $\mathrm{y}$ the writer got score 0,863 . It can be stated that the hypothesis was accepted.

\footnotetext{
${ }^{9}$ ES Harida, “Understanding Paragaraph and Three Phases in Reading Comprehension," English Education: English Journal for Teaching and Learning 4, no. 1 (2016): 102, http://jurnal.iainpadangsidimpuan.ac.id/index.php/EEJ/article/view/1195.

${ }^{10}$ Lubis, "The Comparative Study of Grammar Translation Method (GTM), Task Based Language Teaching (TLBT), and Contextual Learning and Teaching (CLT) in Writing Sentences at SMP Swasta Nurul Ilmi."

${ }^{11}$ Natalie G. Olinghouse and Joshua Wilson, "The Relationship between Vocabulary and Writing Quality in Three Genres," Reading and Writing 26, no. 1 (January 20, 2013): 45-65, https://doi.org/10.1007/s11145-012-9392-5.
} 
324 | TAZKIR: Jurnal Penelitian Ilmu-ilmu Sosial dan Keislaman

Vol. 03 No. 2 Desember 2017

\section{The Suggestion}

Based on the data analysis and conclusion above, the writer feels obliged to offer some suggestion that :

1. The English teacher have to increase their skills in teaching English especially teaching Generic structure and writing Narrative text to improve the students ability English.

2. The English teacher are expected to give motivation to their students, and provided the appropriate materials supply the suitable technique in teaching learning process, especially in teaching generic structure mastery and writing narrative text.

3. To help the students memorize the lesson and to improve their mastery of the lesson, the teacher should give the drill and practice in teaching English in orders to improve students skill. English teacher should try to give the basic understanding of the English.

4. It is suggested to the headmaster to support the teaching learning process in the class. By giving some facilities, such as language labortory, English book etc.

5. The constructive critics from the reader are always welcomed and appreciated and then more deply investigations, from other research of this study are really expected for the next researcher who want to do some as research about generic structure and writing narrative text. 


\section{BIBLIOGRAPHY}

Bretton and Hortory. 1995. Writing Narrative Scientific Research Articles Srategy and The Steps. Australia: Willey Blackwell.

Dietch. 2003. Writing Teaching Guide, Sidney : Langosch.

Harida, ES. "Understanding Paragaraph and Three Phases in Reading Comprehension." English Education: English Journal for Teaching and Learning 4, $\quad$ no. $\quad 1 \quad$ (2016): $102 . \quad$ http://jurnal.iainpadangsidimpuan.ac.id/index.php/EEJ/article/view/1195.

Harmer, Jeremy. "How to Teach English: An Introduction to the Practice of English Language Teaching." Longman Ninth Impression, 1998.

Larsen-Freeman, Diane, and Michael H. Long. An Introduction to Second Langguage Acquisition Research. New York: Routledge Taylor \& Francis Group, 2014.

Linse, Caroline, and David Nunan. Practical English Language Teaching: Young Learners. New: McGraw-Hill Companies, Inc., 2005.

Lubis, Rayendriani Fahmei. “The Comparative Study of Grammar Translation Method (GTM), Task Based Language Teaching (TLBT), and Contextual Learning and Teaching (CLT) in Writing Sentences at SMP Swasta Nurul Ilmi." TAZKIR: Jurnal Penelitian Ilmu-Ilmu Sosial Dan Keislaman 2, no. 1 (August 1, 2016): 159. https://doi.org/10.24952/tazkir.v2i1.408.

Merriam Webster. “Merriam-Webster Dictionary.” merriam-webster.com, 2017. https://www.merriam-webster.com/dictionary/writing.

Olinghouse, Natalie G., and Joshua Wilson. "The Relationship between Vocabulary and Writing Quality in Three Genres." Reading and Writing 26, no. 1 (January 20, 2013): 45-65. https://doi.org/10.1007/s11145-012-9392-5. 
326 | TAZKIR: Jurnal Penelitian Ilmu-ilmu Sosial dan Keislaman Vol. 03 No. 2 Desember 2017

Pembagian Warisan Terhadap Anak Perempuan Di Desa Padang Kahombu Kecamatan Batang Angkola Kabupaten Tapanuli Selatan

\section{TENGGO SUBANGUN HARAHAP}

IAIN Padangsidimpuan 